\title{
APPLICATION OF BUILDING INFORMATION MODELLING AND CONSTRUCTION PROCESS SIMULATION ENSURING VIRTUAL PROJECT DEVELOPMENT CONCEPT IN 5D ENVIRONMENT
}

\author{
Vladimir Popov \\ Vilnius Gediminas Technical University \\ Civil engineering faculty \\ Sauletekio al. 11, LT-10223 Vilnius, Lithuania \\ vlad@inre.lt \\ Virgaudas Juocevicius \\ Vilnius Gediminas Technical University \\ Civil engineering faculty \\ Saulètekio al. 11, LT-10223 Vilnius, Lithuania \\ virgaudas.juocevicius@conserela.IT
}

\author{
Darius Migilinskas \\ Vilnius Gediminas Technical University \\ Civil engineering faculty \\ Saulètekio al. 11, LT-10223 Vilnius, Lithuania \\ darius.migilinskas@st.vgtu.lt \\ Saulius Mikalauskas \\ UAB "Statybu ekonominiai skaiciavimai" \\ Ateities g. 9-524, LT-08304 Vilnius, Lithuania \\ saulius.mikalauskas@ses.lt
}

\begin{abstract}
With the growth of information technologies in the field of construction industry over the last years, numerical building information modeling and process simulation has evolved to a fully accepted and widely used tool for project life circle management. A growing diversity between disciplines, participants, tasks, tools and events while project management in design and construction stages, the rising pressure of costing competition and tighter production deadlines, together with consistently increasing quality requirements and necessity of technological enhancements, have been the driving force of information modeling and numerical simulation in building industry. The range of applications covers virtually every phase of the specific construction product development process: planning, design, estimating, scheduling, fabrication, construction, maintenance and facility management. Theoretical background and practical innovative applications of building information modeling and construction process simulation technique ensuring Virtual Project Development (VPD) concept are observed in the article.
\end{abstract}

\section{KEYWORDS}

information technologies in construction industry, building information modeling, project life circle management, virtual project development. 


\section{INTRODUCTION}

With the growth of information technologies in the field of construction industry over the last years, numerical building information modeling and process simulation has evolved to a fully accepted and widely used tool for project life circle management [1], [2]. A growing diversity between disciplines, participants, tasks, tools and events while project management in design and construction stages [3], the rising pressure of costing competition and tighter production deadlines, together with consistently increasing quality requirements and necessity of technological enhancements, have been the driving force of information modeling and numerical simulation in building industry. The range of applications covers virtually every phase of the specific construction product development process [4], [5], [6], [7]: planning, design, estimating, scheduling, fabrication, construction, maintenance and facility management. Theoretical background and practical innovative applications of building information modeling and construction process simulation technique [6], [8], [9], [10] ensuring Virtual Project Development (VPD) concept [11] are observed in the article.

Therefore problems caused by teams acting apart influence on result of three main project development objectives - time, costs and quality. Today's fast development increases priority of the time target. The project activities delays cause direct increase of financial losses during construction for contractor. The late commissioning of the building delays cash generation for the customer - financial losses. This delay in addition creates conflict between contractor and customer, which very often lead to long dispute resolutions in the court [12].

It is evident, that traditional procedures of the project development with limited use of the IT solutions [1], [2], [3], [4] leads to waste of time for documentation checking, drawing and redrawing, long duration of variation orders resolution during both design and construction stages [8]. The opportunity to have wide analysis and synthesis of alternatives is very limited there. Therefore it is very difficult to find rational solutions [9] and ensure adequate costs for required fit for purpose of the developed premises [13]. Projects' complexity requires multidisciplinary teams, where works are unnecessary duplicated very often [8]. Therefore increased demand of human resources leads to costs increase and inefficiency of the project team [14].

Traditionally project scope is divided by working packages for different disciplines [5], [7], [15]. Then project team organization gets number of the companies different in attitudes, culture and competence in their performance [14]. Therefore coordination and communication between members of the project performers becomes very complex and difficult [5], [16]. This situation leads to increased risk of errors [17], [18] and omissions and at same time restricted design capabilities. It is evident that overall quality of the building goes to lower grade.

\section{5D MODELING AND ANALYSIS}

The constant mutual collaboration between the project's participants is the main obligation to ensure the effective management of construction project [3], [4], [17], [18] and it can be fulfilled by using 5D (five dimensional) modeling concept [8], [11], [19].

The first step in implementation of this "right" management begins with the creation of 3D (three dimensional) model of the project [8]. The second step is the automatically managed (generated) resource demand and cost calculation (estimate), the list of product's specification and bills of quantities [6], [7]. The third step is calculation of duration for certain construction process (together with duration of the whole project) and association of $3 \mathrm{D}$ model elements with time schedule for graphical simulation of construction project's implementation [16], [20]. The forth step is evaluation of possible solutions or even alternative project with multicriteria decision making system [13], [21].

The result of the steps listed above is developed theoretical 3D information model [2] of the building (BIM - building information modeling) consisting of intellectual volume elements, which is combined with resource demand and cost calculations [11], [19], determination of duration and comparison of alternatives for all the stages of investment project life [9], [13], [20], [22]. 
Such expression of 3D model in time within all its life and costs is the project's 5D conception [23]. A constant cycle is being executed within the stages of this 5D concept model (Fig. 1) in order to adopt the best solution, and there is a constant exchange of cycle information flow between the stages encouraging selection of the most effective variant [24]. The structure of 5D concept model is divided into levels: on the first level (cells in bold) stages and their interrelations are presented; on the second level (cells with dotted line) primary data (and means) are presented; the third level (cells with

arrows) is devoted for the actions and processes being carried out; the fourth level (big cells) presents the obtained result, benefit and advantages; in the fifth level the indicators of stages effectiveness are obtained, afterwards used for further multiple criteria comparison of the construction variants.

The principle of $5 \mathrm{D}$ concept model application is as follows: the quantities of modeled, described and parameterized elements [25] are obtained automatically from the developed building information model (3D BIM) [6], [7], and the demand for project resources is generated.

II STAGE

ORGANIZATION AND SIMULATION OF CONSTRUCTION WORKS

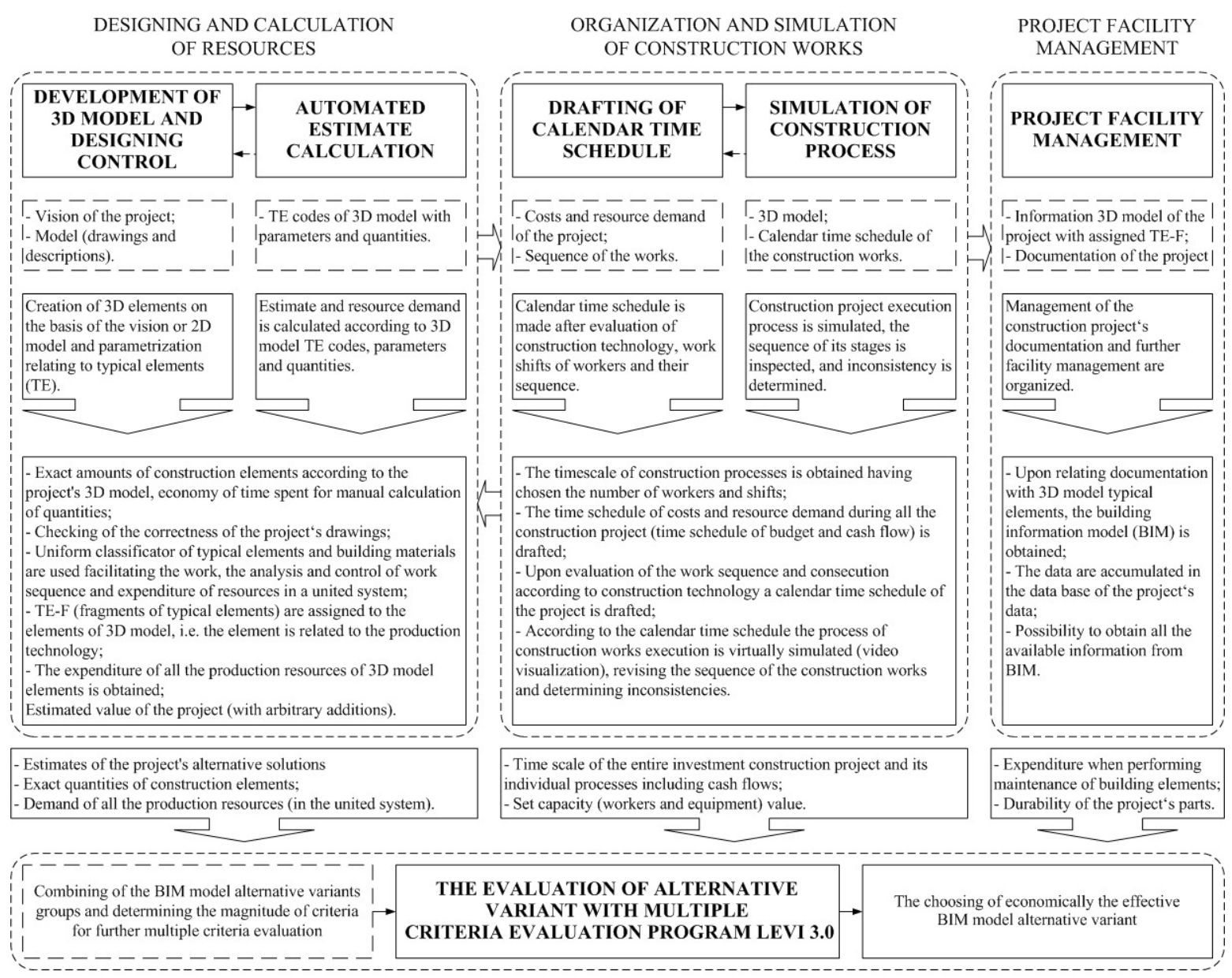

THE COMPARISON OF VARIANTS AND EVALUATION
III STAGE
DESIGNING AND CALCULATION OF RESOURCES

Figure 1. Stages of 5D concept and its elements 
According to set technical capacities, from the resources demand we obtain the timescale of the project's processes [16], from technological sequence of which the time scale of the entire construction project is derived. The advantage using Virtual Project Development [11] is possibility to analyze alternative solutions of implementation (installation). Every stage of the project can be analyzed comparing the selected alternative variants. In this way a flexible simulation and real time analysis are obtained and in the case of any changes (at any stage of the project implementation cycle) alternative solutions can be assessed and the most effective variant chosen [26] using 5D concept and virtual 3D BIM model data.

It is obvious that the primary elements in the model's structure can have the biggest impact and influencing the efficiency indicators [27], and selection of the best alternative mostly depends upon a precise determination of demand for resources, because in case of a mistake, the determined most effective variant can be misguided. Therefore, in order to establish the demand for the project resources, a thorough calculation of the project related quantities is to be made [7], [8], and this work is timeconsuming, as most often the calculation of quantities is performed in a manual way. To reduce the time period necessary for the calculation of the quantities in relation to the construction project and to avoid uncertainties, mistakes and inaccuracies that are possible due to manual calculation, the $5 \mathrm{D}$ concept model can be used.

\section{BIM A NEW APPROACH OF THE DESIGN AND MANAGEMENT}

The essence of the BIM involves the fact that a design is treated as an integral part of the building life cycle [2]. Segmented work between the design parts and members is replaced by the adjusted process. This is achieved by changing the design technology substantially, switching from the development of a set of $2 \mathrm{D}$ drawings to the development of a 3D computer aided model of a building, comprising all the parts of the design, such as architectural, structural, mechanical, technological, construction process management and estimates [15], [16], [19], [24].

In the design stage these goals are implemented by the technology of a Building continuum model, which focuses on the finally completed and fully equipped $3 \mathrm{D}$ building model comprising all the design parts. The base of this technology is made up of the 3D graphical-information model [1], [2], [3] covering the following: building geometrical model; its physical properties (materials, etc.); functional peculiarities of its components.

One of the fundamental innovations of this technology includes component modeling. The component modeling technology [1] allows working in parallel with all design data at the level of data components covering the entire design cycle on the scale of a users group. Engineering components are graphical numerical models of real objects. These models characterize geometry, properties, links, and attributes of the real objects [3]. It is assumed that a building consists of elements and parts different by their functions, properties, and manufacture technology [4]. A part may involve a simple structural component or a complex structure. All elements or parts have specific 3D shape with the properties of the elements of real structures (physical properties, class or standard). They are parametrically controlled and intellectual [5], i.e. each object "knows" about itself both quantitative information (length, area, volume, and etc.) and qualitative information (material, contents). All this provide unlimited possibilities not only to develop objects, to change and edit the shape of objects rapidly and effectively, but also to preserve and manage their attributive information, using the $3 \mathrm{D}$ building model [11].

In the meanwhile 2D information, i.e. different drawings (plans, sections, facades, details, and nodes) and other design documentation (list of materials, specifications, reports, and estimates) are generated from the 3D model. Quantity and price of the specified components may be calculated by the measurement units required taking into account volume, area, length, or just by the parameter entered [6]. Since these reports are linked to the model, new editions of the model update design data 
automatically [8]. If necessary, external databases may be connected and used. Thus, accuracy, coordination, and synchronization of changes in the whole project documentation are ensured.

BIM is the driver with discipline-specific solutions, working together. By applying information and model-based technology solutions to allow the automatic generation of drawings and reports, design analysis [2], cost estimating [7], schedule simulation [16], facilities management, and more - ultimately enabling the building team to focus on the information and their decisions [19], rather than the documentation tools and process [23]. The result is a better way for building teams to work - with time saved, improved quality, and better buildings because of the informed decisions made along the way. Using BIM the entire lifecycle of the building is considered (design/build/operations) [24]. All information about the building and its lifecycle is included defining and simulating the building, its delivery, and operation using integrated tools. BIM integrates work, processes, and information for: multiple disciplines, multiple companies; multiple project phases.

In time aspect during design, there is increased opportunity for design iterations, as information is exchanged between disciplines quickly. Project documentation requires less time wasted on grunt work [23]. Professionals can spend less time documenting decisions and more time making them [13]. Everyone can avoid redundant effort. And construction can better support fast-tracking, tightly managed schedules, and the shared risks and rewards of design/build [17, [18].

In quality aspect using BIM the user has improved coordination between documents, between disciplines, and across the entire team reduces errors and omissions. With coordinated documents and well-captured design intent, the enhanced design process makes for a far more informed design environment [23].

\section{COMPUTER AIDED ESTIMATING SYSTEM IN CONSTRUCTION}

SAS - Computer aided construction estimating system, based on Building Information Modelling concept [3], interconnects structural design, estimating and time shedulling. The main purpose of SAS is to automate the economic part of design a the maximum, providing user (designer, contractor or investor) with possibility to evaluate economic expenditures at any stage of a project - from the design to finished construction. Just-one-click tools enables user to get an estimate (expenditures of resources, supposed operations, cost calculations) with no need to calculate quantities, select work normatives, evaluate conditions - everything is obtained automatically from information model of a construction [6]. An estimate is obtained in a file format of SES2004, and can be edited using the widest functionality of this application and largest databases of wok norms and construction resources (materials, labour, machinery) [8]. As there is references between constructional element (in a model) and estimate, one can acquire any costrelated and expenditure-related information for each such element. Changes in a design can automatically regenerate associated estimate. All information about operations and resources from estimate can be passed to time scheduling applications [16], [24], such as Microsoft Project. All information is stored in a general database, so feedback is widely possible.

SAS Database of typical constructional elements (DTCE) is oriented to topical up-today solutions in construction. The basis of DTCE database is Classificator of typical constructional elements (CTCE), which arranges typical elements into classes, groups and subgroups according to technological processes. Each description of typical element contains code, name, set of parameters, fragment of estimate and a macro, which process fragment depending on parameters (for example, chooses appropriate norms, calculates quantitative information, etc.) [24]. Fragments of estimates for typical elements are based on norms, certified by governmental institutions of Lithuania and Russian Federation. DTCE database can be easily updated by new elements, adapted to any company, it's technology. On purpose to ease the setting of parameters, most of values can be picked from a list; along with numerical parameters, DTCE provides proper versatility; 
According to carried calculations, this system can save up to 40 percents of the time, required for design and economic-technologic calculations, including preparation of drawings, estimates, schedules and analysing a number of alternative versions of a project.

\section{VIRTUAL PROJECT DEVELOPMENT}

Virtual Project Development can be described as complex of works for construction implementation. The possible stages of virtual project development:

1. Conceptual design. Development of preliminary 3D design with volumes and spaces made of hypothetical "match sticks and boxes" both with preliminary simulation of implementation (connection with draft schedule);

2. Design. Final design revision, precise 3D modeling with generated specification, bills of quantities, demand of resource [8], workshop drawings and Technological Work Implementation Design (TWID);

3. Construction. Reliable design connected with project schedule, used as simulation of project implementation, clash control, procurement tracking and mean of strict project organization;

4. Maintenance. Links between 3D model and Project's data, "Walking around" simulation in 3D model and Building Information Modeling data for Facility Management (all information on physically selected element in 3D model).

Technological work implementation design (TWID) of the project must be used to rationally manage project implementation and reduce possible uncertainty. Technological work implementation design can consist of several parts:

1. General site plan (with temporary facilities, temporary engineering systems, storage places, traffic routes, lifting equipment, working zones, danger zones, fencing, security, fire protection means, health and safety at work means);

2. Installation guidance (with description of processes, parameters of cranes or other lifting equipment, plan an section views, strope equipment, load-reach-height diagrams);

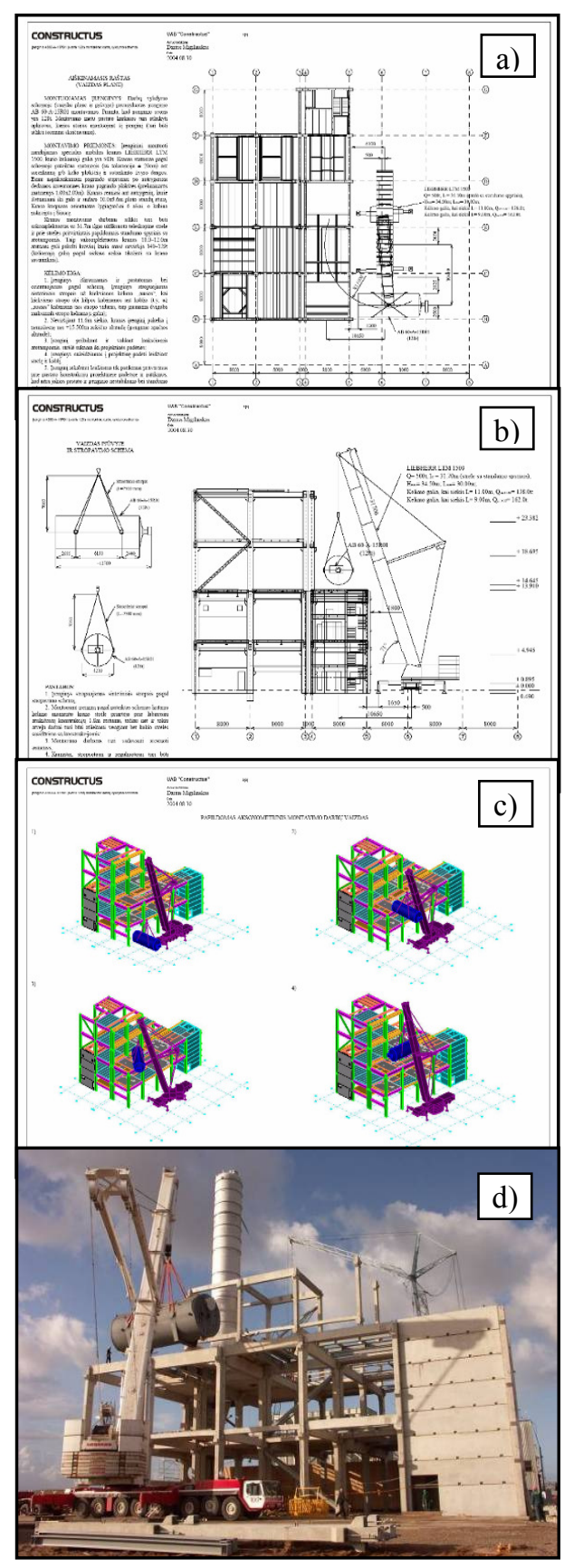

Fig. 2. Technological work implementation 
3. Detailed organizational guidance for certain technological processes (with certain solutions, graphical views, technological order, tools and equipment, health and safety at work means);

4. Estimation for all project and demand of recourses for certain processes;

5. Schedule for all project, work force and machinery demand, cash flow and work sequencing for certain workplaces.

The real 3D model usage in Technological Work Implementation Design is shown in figure 2 there are plan (a) and section (b) views, characteristics of cranes, strope equipment, health-safety at work measures, organizational order with detailed description and isometrics (c),. It presented both with the implementation photos of real installation for certain stages of process (d).

This kind of installation simulation as a part of Technological work implementation design is good example of Virtual Project Development in construction industry [11]. 3D modeling for installation simulation and virtual work implementation management can be used in advance and possible construction clash or crane collision can't be missed or not foreseen.

\section{CONCLUSION}

Theoretical background with practical innovative applications of building information modeling and construction process simulation technique ensuring Virtual Project Development (VPD) concept was observed in the article.

It is obvious that the next evolution of CAD for the building industry and it is upgrading the way that architects, engineers, contractors, and facility managers work and collaborate in BIM according to $5 \mathrm{D}$ concept provides major advantages:

1. BIM models and manages not just graphics, but also information that allows the automatic generation of drawings and reports, design analysis, estimation, schedule simulation, organizing of works and facilities management.

2. BIM facilitates the creation and sharing of information significant for the design, construction, and operations of buildings, over their entire life cycle. It provides a collaborative environment so that project members can effectively share this information by eliminating data redundancy, the need to re-enter data, data loss, miscommunication, and translation errors.

3. According to carried calculations, the estimation system in 5D concept can save up to 40 percents of the time, required for design and economictechnologic calculations, including preparation of drawings, estimates, schedules and analysing a number of alternative versions of a project.

4. Virtual Project Development in construction industry can be used as 3D modeling for installation simulation and virtual work implementation management can be used in advance and possible construction clash or crane collision can't be missed or not foreseen.

\section{REFERENCES}

[1] Ford, S., Aouad, G., Brandon, P., Brown, F., Child, T., Cooper, G., Kirkham, J., Oxman, R., Young, B. (1994) The object oriented modelling of building design concepts, Building and Environment, Vol. 29, No. 4, 411-419.

[2] Hoekstra, J. (2003) Big Buzz for BIM, Architecture, Vol. 92, No. 7, 79-82.

[3] Gabbar, H., A., Aoyama, A., Naka, Y. (2004) Model-based computer-aided design environment for operational design, Computers \& Industrial Engineering, Vol. 46, No. 3, 413-430.

[4] Ford, S., Aouad, G., Kirkham, J., Brandon, P., Brown, F., Child, T., Cooper, G., Oxman, R., Young, B. (1995) An information engineering approach to modelling building design, Automation in Construction, Vol. 4, No. 1, 5-15.

[5] Garner, B., Raban, R. (1999) Context management in modeling information systems (IS), Information and Software Technology, Vol. 41, No. 14, 957-961.

[6] Popovas, V., Ustinovichius, L., Mikalauskas, S. (2004) Technique for computer aided evaluation of economic indicators of a construction project, Selected papers of The 8th International Conference 
„Modern building materials, structures and techniques", Vilnius, Lithuania, May 19-21, 242248.

[7] Chapman, C., Ward, S. (2003) Constructively simple estimating: a project management example, Journal of the Operational Research Society, Vol. 54, No. $10,1050-1058$.

[8] Ustinovičius, L., Popov, V., Migilinskas, D. (2005) Automated management, modeling and choosing of economically effective variant in construction, Transport and Telecommunication, Vol. 6, No. 1, 183-189.

[9] Zavadskas, E.K.; Peldschus, F. and Ustinovichius, L. (2003) Development of software for multiple criteria evaluation, Informatica, Vol. 14, No. 2, 259-272.

[10] Kopytov, E.; Greenglaz, L. and Tissen, F. (2006) Stochastic inventory control model with two stages in ordering process, Journal of business economics and management, Vol. 7, No. 1, 21-24.

[11] Leinonen, J. and Kähkönen, K. (2003) New construction management practice based on the virtual reality technology, In: $4 D C A D$ and Visualization in Construction. Issa, R.R.A., Flood, I., O'Brien, W.J. (Eds.), A.A. Balkema Publishers, Lisse, 75-100.

[12] Mitkus, S. and Trinkūnienè, E. (2006) Models of indicator systems of construction contraction agreements, Journal of Civil Engineering and Management. Vol. 12, No. 4, 327-335.

[13] Ustinovičius, L., Šarkienė, E. and Šarka, V. (2003) Model of efficient architectural decisions of dwelling - houses applying the method of project multicriteria decision synthesis. Technological and economic development of economy, Vol. 9, No. 1, 18-26.

[14] Cardoso Teixeira, J., M., Minasowicz, A., Zavadskas, E., K., Ustinovichius, L., Migilinskas, D., Pellicer Armińana, E., Nowak, P. O. and Grabiec, M. (2006) Training needs in construction project management: a survey of 4 countries of the EU, Journal of Civil Engineering and Management, Vol. 12, No. 3, 237-245.

[15] Miedziałowski, C., Chyży, T., Krętowska, J. (2007) Numerical model of three-dimensional coupled wall structures, Journal of Civil Engineering and Management. Vol. 13, No. 1, 37-45.

[16] Donath, D., Loemker, T., M. and Richter, K. (2004) Plausibility in the planning process - reason and confidence in the computer-aided design and planning of buildings, Automation in Construction, Vol. 13, No 2, 159-166.

[17] del Cańo, A. and Pilar de la Cruz, M. (2002) Integrated Methodology for Project Risk Management, Journal of Construction Engineering and Management, Vol. 128, No. 6, 473-485.

[18] Huchzermeier, A. and Loch, C.H. (2001) Project management under risk: Using the real options approach to evaluate flexibility in $R \& D$, Management Science, Vol. 47, No. 1, 85-101.

[19] de Vries, B. and Broekmaat, M. (2003) Implementation Scenarios for 4D CAD in Practice, In: Maas, G. and van Gassel, F. (eds.): Proceedings of the 20th International Symposium on Automation and Robotics in Construction. Eindhoven University of Technology. Eindhoven, NL, 393-398.

[20] Nowak, M. (2005) Investment projects evaluation by simulation and multiple criteria decision aiding procedure, Journal of civil engineering and management. Vol. 11, No. 3, 193-202.

[21] Zavadskas, E., K., Ustinovichius, L., Turskis, Z., Peldschus, F., Messing, D. (2002) LEVI-3.0 multiple criteria evaluation program for construction solutions. Journal of Civil Engineering and Management, Vol. 8, No. 2, 184-191.

[22] Antuchevičienè, J., Turskis, Z. and Zavadskas, E., K. (2006) Modelling renewal of construction objects applying methods of the game theory, Technological and economic development of economy, Vol. 12, No. 4, 263-268.

[23] Migilinskas, D. and Ustinovichius, L. (2006) Computer-aided modelling, evaluation and management of construction project according PLM concept, Lecture Notes in Computer Science. LNCS, Vol. 4101, 242-250.

[24] Popov, V., Mikalauskas, S., Migilinskas, D. and Vainiunas, P. (2006) Complex usage of 4D information modeling concept for building design, estimation, scheduling and determination of 
effective variants, Technological and economic development of economy, Vol. 12, No. 2, 91-98 .

[25] Sacks, R., Eastmanand, C., M., and Lee, G. (2004) Parametric 3D modeling in building construction with examples from precast concrete, Automation in Construction, Vol. 13, No. 3, 291-312.

[26] Ginevičius, R. and Podvezko, V. (2005) Generation of a set of evaluation criteria, Business: Theory and Practice, Vol. 6, No. 4, 199-207.

[27] Viteikienè, M., Zavadskas, E., K. (2007) evaluating the sustainability of Vilnius city residential areas, Journal of Civil Engineering and Management, Vol. 13, No 2, 149-155. 